УДК 347.51

DOI https://doi.org/10.32849/2663-5313/2021.6.10

\title{
Володимир Примак,
}

докт. юрид. наук, провідний науковий співробітник

Науково-дослідного інституту приватного права і підприємниитва імені академіка Ф.Г. Бурчака Начіональної академії правових наук України

\section{ВІДШКОДУВАННЯ ШКОДИ, ЗАВДАНОї У ЗВ'ЯЗКУ З ВАКЦИНАЦІЕЮ ВІД COVID-19}

У статті досліджуються правові проблеми, зумовлені перетином сфер функиіонування відмінних одне від одного правових механізмів - відповідно, переважно приватноправового або публічно-правового регулювання відносин із відшкодування шкоди, заподіяної пачієнтам та іншим особам унаслідок дій або бездіяльності професіоналів у иарині медичного обслуговування, провайдерів медичних послуг насамперед. Розглядаються особливості взаємодії норм деліктного права та приписів умовно страхового (сочіального, заснованого на ідеї солідарності) спрямування, запроваджені новітнім вітчизняним «антиковідним» законодавством і міжнародно-правовими положеннями Програми компенсації без вини COVAX.

Наголошується, шо, на відміну від Програми компенсаиї̈ без вини COVАX, начіональний правовий механізм, установлений Постановою Кабінету Міністрів України «Деякі питання державної компенсаиії шкоди, пов'язаної з ускладненнями, що можуть виникнути після вакиинації від гострої респіраторної хвороби COVID-19, спричиненої коронавірусом SARS-CoV-2» вid 31.03.2021 № 371, не охоплює таких юридично значимих аспектів правового захисту потерпілих осіб, як представниитво інтересів потерпілої особи; широке коло істотних виявів шкоди, що може бути спричинена вакиинаиією (відповідний перелік не можна обмежувати лише такими обставинами, як смерть фізичної особи або їі інвалідність); закріплення надійного стандарту встановлення причинно-наслідкового зв'язку (такого, наприклад, як стандарт найімовірнішої причини згідно з Програмою компенсачії без вини COVAX); адміністративна прочедура апелящійного оскарження рішення уповноваженого органу; можливість правонаступничтва (у тому числі процесуального) щодо вимог померлого пачієнта; порядок обміну конфідениійною інформачією про пачієнта; урахування правових наслідків недобросовісних дій заявників (щодо отримання компенсаиї) і третіх осіб тощо.

Ключові слова: пандемія COVID-19, надзвичайні обставини, иивільно-правова (договірна або деліктна) відповідальність, пачієнт, провайдери медичних послуг, інвалідність, вакцина.

Постановка проблеми. Пандемія короновірусної хвороби COVID-19 радикально змінила весь уклад життедіяльності людства незалежно від національної та іншої специфіки окремих суспільств і державно-правових утворень. Нині, як і у кожному випадку виникнення нового чинника об'єктивної дійсності, спроможного істотно впливати на інтереси учасників цивільних відносин, яскраво проявляється природний симбіоз регулятивної та охоронної функцій цивільного права, адже саме він диктує необхідність унесення коректив до механізмів правового регулювання взаємопов'язаних регулятивних та охоронних відносин, на які вирішальною мірою впливає нововиникла обставина.

Особливо рельєфно зміна характеру та способів такої взаємодії регулятивних та охоронних засад приватного права постає у сфері абсолютних цивільних відносин особистих немайнових насамперед, включно
3 тими, змістом яких є право людини на охорону здоров'я. А серед способів цивільноправового захисту цього права домінують такі заходи цивільно-правової відповідальності, що застосовуються до провайдерів медичних послуг, як відшкодування завданої пацієнтам майнової та моральної шкоди [1].

у межах різних правових систем цивільно-правовий захист потерпілих у сфері медичного обслуговування надається передовсім за допомогою заходів або договірної або (переважно) позадоговірної (деліктної) відповідальності [2]. Водночас цивільно-правова відповідальність професіонала нерідко замінюється виплатами за рахунок фондів соціального (публічного) або приватного страхування [3]. Причому зазначені складники правового регулювання - застосування заходів цивільно-правової відповідальності й механізмів страхування - можуть бути задіяні в найрізноманітніших варіантах їх поєднання. 
В Україні протягом останніх п'яти років питання цивільно-правової відповідальності постають як майже неодмінний складник комплексних цивілістичних досліджень у сфері надання медичних послуг, медичного обслуговування загалом, а також при обговоренні зазначеної проблематики на наукових заходах $[4 ; 5 ; 6 ; 7]$. Утім стрімке поширення пандемії COVID-19 і надзвичайні заходи, що вживаються з метою її припинення на національному й міжнародному рівні, змушують переглянути усталені моделі компенсаційного захисту пацієнтів саме в площині взаємодії приватноправових і публічно-правових засобів відповідного спрямування.

Метою статті $\epsilon$ визначення вектору адаптації механізмів відшкодування шкоди, завданої пацієнтам та іншим особам у сфері охорони здоров'я, у контексті вакцинації від COVID-19.

Виклад основного матеріалу. У зв'язку 3 «втручанням» в усталений перебіг цивільних відносин певного виду надзвичайних обставин у фокусі уваги правознавців опиняються питання забезпечення першочергової реалізації притаманного європейському приватному праву основоположного принципу безпеки, при цьому останній, взаємодіючи 3 принципами справедливості й ефективності, нині подекуди ніби відтісняє на другий план принцип свободи [8]. Проте, якою б не була надзвичайна ситуація, саме їі виникнення спричиняє формування суспільного запиту щодо адаптації під нововиниклу життєву ситуацію чи не всіх елементів механізму цивільно-правового регулювання. Ідеться не тільки про прийняття спеціальних нормативно-правових актів нерідко комплексного (приватно-публічного) змісту на національному рівні, які характеризує певне зміщення наголосів - зі сфери приватноправової на сферу публічно-праву, з виявів диспозитивного методу на вплив виразно імперативних приписів [9], а й про створення нових джерел права глобального значення, у нормах яких закріплюються нові юридичні факти (склади), а також правові наслідки їх виникнення включно з адаптованими або новоствореними способами захисту [10]. Усе частіше компенсаційний захист пацієнтів у різних країнах реалізується за допомогою організаційних форм постійної взаємодії представників пацієнтів та адміністрацій медичних закладів, створення спеціальних компенсаційних фондів на випадок заподіяння шкоди, що не підлягає відшкодуванню за правилами деліктної відповідальності або не покривається достатньою мірою за рахунок страхових виплат [11], експертної та дис- циплінарної діяльності професійних медичних асоціацій тощо.

I тут сьогодні у фокусі уваги опиняються норми деліктного права у взаємодії з положеннями умовно страхового (соціального, заснованого на ідеї солідарності) спрямування, запроваджені новітнім вітчизняним «антиковідним» законодавством і міжнародно-правовими положеннями Програми компенсації без вини COVAX.

Так, Постанова Кабінету Міністрів України «Деякі питання державної компенсації шкоди, пов'язаної 3 ускладненнями, що можуть виникнути після вакцинації від гострої респіраторної хвороби COVID-19, спричиненої коронавірусом SARS-CoV-2》 від 31.03.2021 № 371 (далі - Постанова КМУ) прийнята (як випливає 3 її преамбули) відповідно до п. 3 розділу «ІІ Прикінцеві положення» Закону України «Про внесення зміни до Закону України «Про лікарські засоби» щодо державної реєстрації лікарських засобів під зобов'язання для екстреного медичного застосування» від 29.01.2021 № 1159-IX, п. 3 розділу II «Прикінцеві положення» Закону України «Про внесення зміни до статті 9-2 Закону України «Про лікарські засоби» щодо державної реєстрації вакцин або інших медичних імунобіологічних препаратів під зобов'язання» від 19.03.2021 № 1353-IX (далі - Закон України від 19.03.2021 № 1353-IX) та п. 24 ст. 14 Закону України «Про Державний бюджет України на 2021 рік».

Згаданою Постановою КМУ затверджено Порядок здійснення державної компенсації шкоди, пов'язаної з ускладненнями, що можуть виникнути після вакцинації від гострої респіраторної хвороби COVID-19, спричиненої коронавірусом SARS-CoV-2, і Порядок використання коштів, спрямованих на здійснення державної компенсації шкоди, пов'язаної з ускладненнями, що можуть виникнути після вакцинації від гострої респіраторної хвороби COVID-19, спричиненої коронавірусом SARS-CoV-2.

При цьому вказаним у преамбулі до Постанови КМУ Законом України від 19.03.2021 № 1353-ІХ начотири наступні роки 3 дня набуття цим Законом чинності ст. 9-2 Закону України «Про лікарські засоби» від 04.04.1996 № 123/96-ВР доповнено новою ч. 6 такого змісту: Щісля державної реєстрації вакцин або інших медичних імунобіологічних препаратів для специфічної профілактики коронавірусної хвороби (COVID-19) під зобов'язання для екстреного медичного застосування центральний орган виконавчої влади, що забезпечує формування та реалізує державну політику у сфері охо- 
рони здоров'я, за рішенням Кабінету Міністрів України має право брати зобов'язання від імені України, пов'язані із закупівлею, застосуванням вакцин або інших медичних імунобіологічних препаратів для специфічної профілактики коронавірусної хвороби (COVID-19), державна реєстрація яких здійснена відповідно до вимог цієї статті, у тому числі щодо відмови від суверенного імунітету щодо таких зобов'язань, а також звільнення від відповідальності виробника та/або власника реєстраційного посвідчення, включаючи їх працівників, медичних працівників, якщо застосування таких вакцин або інших медичних імунобіологічних препаратів здійснювалось відповідно до інструкції, затвердженої центральним органом виконавчої влади України, що забезпечує формування та реалізує державну політику у сфері охорони здоров'я, та інших осіб, які залучені до здійснення заходів, пов'язаних із вакцинацією, за будь-які наслідки, спричинені застосуванням таких вакцин або інших медичних імунобіологічних препаратів для специфічної профілактики коронавірусної хвороби (COVID-19).

У разі настання таких наслідків державою забезпечується здійснення відповідних компенсаційних виплат у порядку, встановленому Кабінетом Міністрів України».

Позначена в такий спосіб компенсаційна правова модель може бути охарактеризована 3 погляду ймовірного кола потерпілих унаслідок невдалого медичного втручання та конкретизації потенційних суб'єктів відповідальності (при тому що найчастіше як суб’єкт відповідальності постає безпосередньо провайдер медичної послуги при фактичному їі наданні його найманими працівниками відповідно до загальних положень про деліктну або договірну відповідальність).

Виходячи 3 кола суб'єктів, потенційно звільнених від відповідальності, вищенаведеними приписами Закону України від 19.03.2021 № 1353-IX і Постанови КМУ внесено істотні зміни в усталений порядок функціонування механізму цивільно-правової відповідальності у сфері медичного обслуговування загалом, а не тільки у відносинах із безпосереднього надання медичних послуг. Крім того, формально вихід медичних працівників, які здійснюють вакцинацію, за межі інструкції із застосування лікарського засобу (вакцини) даватиме змогу порушувати питання про саму можливість здійснення відповідних компенсаційних виплат. Точніше, виходячи з системного (у взаємозв'язку з нормами глави 82 Цивільного кодексу (далі - ЦК) України) і телеологічного тлумачення норм Постанови КМУ, у такого роду ситуації потерпілі незалежно від їхньої волі можуть позбавлені можливості скористатися доволі доступним (тож у цій частині ефективним), компенсаційним механізмом, закріпленим у вказаному правовому акті.

Окрема прогалина виникає в площині реалізації потенціалу кримінально-правового захисту пацієнтів, адже можливість відшкодування шкоди, заподіяної пацієнтові або членам його сім'ї та утриманцям (у разі смерті пацієнта), безпосередньо за вироком суду в кримінальній справі або спираючись на його преюдиціальне значення, слугує надзвичайно дієвим інструментом реалізації прав людини на справедливий суд та ефективний засіб юридичного захисту. I навпаки, норми Закону України від 19.03.2021 № 1353-IX і Постанови КМУ спричинюють нині нерозв'язну колізію з нормами кримінального процесу щодо цивільного позову в кримінальній справі, нівелюючи його роль у забезпеченні приватних інтересів пацієнтів і пов'язаних із ними осіб.

До речі, зважаючи на адміністративноправовий базис гарантій захисту цивільних прав пацієнтів за Постановою КМУ, доцільно вслід за зарубіжними правознавцями пильніше придивитися до однієї поки що доволі рідкісної, але в перспективі надзвичайно важливої точки перетину сфер функціонування відмінних одне від одного правових механізмів, відповідно, переважно приватноправового й публічно-правового регулювання. Такою точкою може виявитися цивільно-правова відповідальність суб'єктів владних повноважень (як відповідний приклад у юридичній літературі згадується Польща) [12]. Передовсім ідеться про випадки, у яких саме неналежне виконання функцій державного регулятора, покладених на спеціально уповноважений орган, вирішальною мірою спричинило заподіяння шкоди пацієнтові (скажімо, у разі відсутності ефективного контролю за діяльністю медичних закладів або приватно практикуючих лікарів, за необгрунтованої видачі дозволу на провадження ними професійної діяльності всупереч їх невідповідності ліцензійним умовам тощо). Не виключено, що підставою для пред'явлення такого роду позовів можуть виявитися й протиправні дії або бездіяльність уповноважених органів державного управління (МО3 України насамперед) 3 організації вакцинації.

Недарма в науковій літературі поряд із діагностичними й терапевтичними лікарськими помилками та порушенням обов'язків з інформування пацієнта виділяють організаційні, або адміністративні, помилки, най- 
частіше такі як порушення санітарно-гігієнічних норм, обов'язків щодо забезпечення ліками або безпеки обладнання зокрема [13]. Вочевидь, цей перелік може бути розширений через охоплення сфери повноважень спеціально уповноважених органів державної влади.

У разі виникнення подібних спорів варто зважати на об'єктивний (з виключенням вини зі складу умов цивільно-правової відповідальності) характер обов'язку держави (статті 1173-1176 ЦК України) як сторони деліктних зобов'язань щодо відшкодування шкоди, завданої її представниками як суб'єктами владних повноважень, адже внаслідок порушення ними своїх обов'язків у публічних правовідносинах виникає шкода на боці потерпілих суб'єктів цивільного права.

Натомість виключення вини зі складу умов цивільно-правової відповідальності провайдерів медичних послуг як суб'єктів господарювання спирається на загальні положення про відповідальність підприємців за порушення договорів про надання послуг (ст. 906 ЦК України), а також як володільців джерел підвищеної небезпеки (ст. 1187 ЦК України) та виконавців послуг, недоліками яких заподіяно шкоду (ст. 1209 ЦК України). Підставами запровадження таких норм насамперед $\epsilon$ прагнення забезпечити справедливий баланс інтересів сторін нововиниклих деліктних зобов'язань і посилений захист слабкої сторони порушених регулятивних правовідносин.

Згідно з Постановою КМУ, проводиться разова виплата в розмірах 400-кратного, 350-кратного, 300-кратного і 750-кратного розміру прожиткового мінімуму для працездатних осіб, відповідно, для осіб з інвалідністю I, II, III групи, у разі встановлення потерпілій особі групи інвалідності, пов'язаної з ускладненнями, що можуть виникнути після вакцинації від гострої респіраторної хвороби COVID-19, спричиненої коронавірусом SARS-CoV-2, і в разі смерті особи, що настала внаслідок зазначеної вакцинації.

Таким чином, поза сферою дії Постанови КМУ виявляються можливі випадки заподіяння майнової (незалежно від ії̈ обсягу) та моральної (загалом) шкоди через асоційовані з вакцинацією ускладнення - ушкодження здоров'я (незалежно від глибини і тривалості страждань потерпілої особи), які не призвели до інвалідності або смерті пацієнта.

Варто наголосити на тому, що в контексті балансування інтересів пацієнтів, виробників вакцин і держави (щодо забезпечення охорони здоров'я населення) закріплена жорстка альтернативність національних і міжнародних механізмів захисту потерпілих осіб, а так само публічно-правових гарантій і засобів деліктного права. Так, у разі отримання пацієнтом виплати на компенсацію шкоди, пов'язаної з ускладненнями, що можуть виникнути після вакцинації від гострої респіраторної хвороби COVID-19, спричиненої коронавірусом SARS-CoV-2, вакцинами або іншими медичними імунобіологічними препаратами для специфічної профілактики коронавірусної хвороби (COVID-19) за процедурою Всесвітньої організації охорони здоров’я в рамках глобальної ініціативи «COVAX», виплати державної компенсації, передбачені Постановою КМУ, не здійснюються. Своєю чергою, згідно з Програмою компенсації без вини COVAX, особа, що скористалася відповідним механізмом, повністю відмовляється від права вимагати й/або отримати компенсацію щодо завданої шкоди від будь-якої іншої програми компенсації чи страхування або будь-якими іншими способами.

Разом із тим, зважаючи на сукупність критеріїв визначення кола суб'єктів права на отримання відповідних виплат, вітчизняний компенсаційний механізм, запроваджений Постановою КМУ, не може розглядатися як повноцінна альтернатива Програми компенсації без вини COVAX. По-перше, саме тому, що дія затвердженого Постановою КМУ Порядку здійснення державної компенсації шкоди, пов'язаної з ускладненнями, що можуть виникнути після вакцинації від гострої респіраторної хвороби COVID-19, спричиненої коронавірусом SARS-CoV-2, поширюється виключно на здійснення виплат державної компенсації шкоди в разі встановлення особам інвалідності або смерті осіб, пов'язаної з ускладненнями, що можуть виникнути після вакцинації від гострої респіраторної хвороби COVID-19, спричиненої коронавірусом SARS-CoV-2.

Тобто в національному праві України виникає прогалина щодо забезпечення інтересів потерпілих, здоров'ю яких завдано істотної шкоди іншого гатунку. При цьому наявна невизначеність є доволі позірною (лише 3 огляду на законодавчу «недомовку»), тому що, відповідно до норм Закону України від 19.03.2021 № 1353-IX і Постанови КМУ, потерпілі пацієнти, яким не буде встановлено інвалідності, виявляться цілком позбавленими можливості скористатися гарантіями, що встановлені в цих правових актах. При цьому зазначені пацієнти не будуть мати права на пред’явлення позову про відшкодування майнової та моральної шкоди до 
виробника вакцини або провайдера медичних послуг, який забезпечував проведення вакцинації. Іншими словами, для пацієнтів розглянутої групи створюються ледь не нездоланні перешкоди в реалізації передбаченого ст. 13 Конвенції про захист прав людини і основоположних свобод 1950 р. права на ефективний засіб юридичного захисту.

Натомість Програма компенсації без вини COVAX хоча й не передбачає компенсації за будь-які несерйозні несприятливі події (так само як і за будь-які серйозні або несерйозні побічні явища, що виникають від будь-якої вакцини проти COVID-19, яка не була отримана через Службу COVAX), однак охоплюе значно ширше коло «серйозних» підстав для виплати компенсацій включно з госпіталізацією потерпілої особи принаймні на строк від однієї доби.

По-друге, деякі з установлених Постановою КМУ підстав для відмови в отриманні передбачених нею виплат не відповідають вимогам справедливості. Наприклад, смерть заявника аж ніяк не можна цілком беззастережно віднести до тих юридичних фактів, що мали б припиняти існування обов'язку держави виплатити компенсацію за шкідливі наслідки введення вакцини. На нашу думку, ураховуючи системне тлумачення норм цивільного й цивільного процесуального законодавства, а так само застосовуючи аналогію закону, суди в разі виникнення спорів мають виходити 3 виникнення в спадкоємців померлого пацієнта права на отримання вищезгаданих виплат у порядку спадкування, хоча б у разі вчасного звернення спадкодавця за їх отриманням (за його життя, 3 наступним після смерті пацієнта процесуальним правонаступництвом).

у плані визначення перспективності новостворених гарантійних механізмів публічно-правового характеру можна констатувати, що вітчизняний компенсаційний механізм захисту від імовірних для окремих осіб негативних наслідків уведення вакцини від COVID-19, по суті (відповідно до мети, проте аж ніяк не за формою його втілення і порядком застосування), становить певного роду сурогат імовірного правового механізму, що міг би діяти на постійній основі в межах загальнообов'язкового державного соціального страхування. При цьому розробку окреслених Законом України від 19.03.2021 № 1353-IX і Постановою КМУ правових конструкцій стимулювала розробка та впровадження на міжнародному рівні Програми компенсації без вини COVAX. Остання, своєю чергою, відображає нині вже досить тривалий національний досвід низки країн із застосування страхового інструментарію для гарантованого відшкодування шкоди, завданої пацієнтам при наданні медичних послуг, у тому числі навіть за відсутності підстав для покладення тягаря цивільно-правової відповідальності на провайдерів зазначених послуг.

Тому зіставлення основних положень національного деліктного і страхового права тієї або іншої країни, з одного боку, і вищезазначеної Програми компенсації без вини COVAX (насамперед протоколу до неї) - $з$ іншого, становить значний науковий і практичний інтерес, адже йдеться про таке: а) з'ясування закономірностей правового регулювання відносин, що виникають у зв'язку із заподіянням асоційованої з вакцинацією шкоди; б) вибір найбільш ефективних правових засобів і конструювання дієвого алгоритму їх застосування; в) забезпечення безконфліктного функціонування всіх наявних в окресленій сфері компенсаційних механізмів (одержання виплат через реалізацію: деліктних зобов'язань, різного роду правовідносин страхування (у межах цивільних правовідносин або відносин загальнообов'язкового державного соціального страхування), нарешті, спеціальних гарантій, запроваджених нормами публічного права, виплати за якими забезпечуються національними публічними або міжнародними грошовими фондами).

Серед іншого в цьому ключі важливо відмітити, що, на відміну від Програми компенсації без вини COVAX, національний механізм, установлений Постановою КМУ, не передбачає представництва інтересів потерпілої особи, закріплення надійного стандарту встановлення причинно-наслідкового зв'язку (стандарт найімовірнішої причини) та адміністративної процедури апеляційного оскарження прийнятого рішення.

Водночас, виходячи 3 положень Програми компенсації без вини COVAX (узагальнено), стандарт найімовірнішої причини включає такі складники, як вилучення 3 кола юридично значимих причин заподіяння шкоди пацієнтові всіх попередніх ушкоджень його здоров'я, оскільки їх не було спричинено вакциною або її введенням; наявність науково обгрунтованої констатації того, що саме вакцина або ї̈ введення були найбільш імовірною причиною заявленого ушкодження, тоді як останньої на момент уведення вакцини не було. Зазначений підхід до визначення причинно-наслідкового зв'язку запроваджує своєрідну презумпцію його наявності за відсутності достатньо переконливих доказів іншого. Звичайно, така інтерпретація найбільшою мірою сприяє реалізації інтересів потерпілих осіб, а тому вста- 
новлений Програмою компенсації без вини COVAX стандарт найімовірнішої причини має бути сприйнято вітчизняним правом і впроваджено в медичну практику та практику правозастосування.

Водночас у межах різних національних правових систем спостерігається певна варіативність у розподілі між сторонами відповідних судових проваджень процесуальних обов'язків у доказовій діяльності й визначенні панівного стандарту доказування умов відповідальності. Так, при встановленні причинно-наслідкових зв’язків між порушенням правил надання медичної допомоги та завданою шкодою італійські суди орієнтуються на логічно передбачуваний результат протиправної поведінки, який установлюється за стандартом «переваги доказів» і за допомогою критерію «більш імовірно, ніж ні» [14]. Видається, що аналогічна концепція сприйнята й утілена в Програмі компенсації без вини COVAX через формалізацію стандарту найімовірнішої причини.

У визначенні розміру належної потерпілій особі компенсації методологія COVAX також виглядає значно гнучкішою за підходи, закріплені в Постанові КМУ, оскільки охоплює не тільки критерій тяжкості заподіяної шкоди (сума, що підлягає сплаті, розраховується через множення ВВП на душу населення відповідної економіки на 12i на коефіцієнт тяжкості завданої шкоди), а й другий об'єктивний критерій - госпіталізацію (ідеться про сплату 100,00 доларів на день за кожен день госпіталізації, що не має перевищувати максимального строку виплат у 60 днів).

Дивовижно відрізняються одне від одного й закладені в нормах Постанови КМУ та в положеннях Програми компенсації без вини COVAX ціннісні критерії, що слугують підгрунтям для визначення розмірів компенсацій, належних потерпілим особам, адже коефіцієнти шкоди, спричиненої вакциною або її введенням, за Програмою компенсації без вини COVAX дорівнюють таким величинам: 1,0 - у разі заподіяння смерті; 1,5 - якщо ушкодження дорівнює або перевищує 75\%; 1,0 - якщо його рівень дорівнює або перевищує 50\%, але менше 75\%; 0,5 - дорівнює або перевищує 25\%, але менше 50\%; 0,25 - дорівнює або перевищує $10 \%$, але менше $25 \%$; 0,10 - якщо ушкодження менше 10\%; 1,5 якщо вроджена травма або хвороба, що спричиняє погіршення, дорівнює або перевищує $75 \% ; 1,0$ - коли вроджена вада або хвороба зумовила погіршення, що дорівнює або перевищує $50 \%$, але менше $75 \%$; 0,5 - якщо вроджена травма або хвороба, що спричиняе погіршення, дорівнює або перевищує 25\%, але менше 50\%; 0,25 - якщо вроджена травма чи хвороба, що спричиняє погіршення, дорівнює або перевищує 10\%, але менше $25 \%$; 0,10 - якщо вроджена травма або хвороба, що спричиняє погіршення здоров'я, менше $10 \%$.

Таким чином, найбільші виплати Програма компенсації без вини COVAX пов'язує не з фактом смерті пацієнта, а з найістотнішими ушкодженнями, що зумовлюють утрату найважливіших життєвих можливостей пацієнтом, який залишився живим, або $€$ новонародженою дитиною $з$ вродженими вадами чи хворобами, спричиненими введенням вакцини її матері (а потенційно й будькому з батьків).

Програма компенсації без вини COVAX, на відміну від Постанови КМУ, установлює також спеціальні правові наслідки недобросовісності заявника або інших осіб у разі фальсифікації, спотворення або неповідомлення ними будь-якої інформації, що має істотне значення.

У Програмі компенсації без вини COVAX урегульовано й важливі аспекти використання конфіденційної інформації про пацієнта або іншого заявника. Останній, подаючи будь-яку заяву про компенсацію за цією Програмою, надає згоду на обмін персональними даними (включаючи інформацію про завдані ушкодження) між органами та особами, які беруть участь в адмініструванні зазначеної Програми, розгляді заяви, претензій, апеляцій. При цьому відносно визначено конкретизується мета організації та проведення такого інформаційного обороту - передусім це збір даних для оцінки пов'язаних із вакцинами ризиків, запобігання будь-якій неправомірній діяльності й виявлення будь-якої неправомірної діяльності. Крім того, наголошується на необхідності додержання пропорційності між такого роду легітимними цілями й ужитими заходами.

\section{Висновки}

На підставі вищевикладеного можна дійти таких висновків:

1. В умовах пандемії короновірусної хвороби COVID-19 простежується увиразнення об'єктивних закономірностей щодо формування міжгалузевих правових механізмів захисту цивільних прав пацієнтів, що поєднують суміжний інструментарій матеріальних галузей публічного і приватного права, цивільно-правової відповідальності та страхування (у межах як цивільних правовідносин, так і відносин загальнообов'язкового соціального страхування), кримінальної, адміністративної та цивільної юстиції, а також різноманітних процедур позасудового вирішення спорів. 
2. На відміну від Програми компенсації без вини COVAX, національний правовий механізм, установлений Постановою Кабінету Міністрів України «Деякі питання державної компенсації шкоди, пов'язаної 3 ускладненнями, що можуть виникнути після вакцинації від гострої респіраторної хвороби COVID-19, спричиненої коронавірусом SARS-CoV-2» від 31.03.2021 № 371, не охоплює таких юридично значимих аспектів правового захисту потерпілих осіб, як представництво інтересів потерпілої особи; широке коло істотних виявів шкоди, що може бути спричинена вакцинацією (відповідний перелік не можна обмежувати лише такими обставинами, як смерть фізичної особи або її інвалідність); закріплення надійного стандарту встановлення причинно-наслідкового зв'язку (такого, наприклад, як стандарт найімовірнішої причини згідно з Програмою компенсації без вини COVAX); адміністративна процедура апеляційного оскарження рішення уповноваженого органу; можливість правонаступництва (у тому числі процесуального) щодо вимог померлого пацієнта; порядок обміну конфіденційною інформацією про пацієнта; урахування правових наслідків недобросовісних дій заявників (щодо отримання компенсації) і третіх осіб.

3. Поряд із провайдерами медичних послуг суб'єктами цивільно-правової відповідальності за заподіяння шкоди у сфері медичного обслуговування можуть поставати також і спеціально уповноважені органи державної влади. При цьому варто зважати на об'єктивний (із виключенням вини зі складу умов відповідальності) характер обов'язків боржників за відповідними деліктними зобов'язаннях.

\section{Список використаних джерел:}

1. Постанова Касаційного цивільного суду в складі Верховного Суду від 04.03.2020 у справі № 641/3547/17. URL: https://reyestr.court.gov.ua/ Review/88337631.

2. The Development of Medical Liability / Ewoud Hondius (ed.). Cambridge : Cambridge University Press, 2014. P. 71.

3. Malpractice and professional liability of medical personnel / Silviu Pituru, Simona Vlădăreanu, Silviu Păun, Andrei Nanu. Farmacia. 2015. Vol. 63. № 2. P. 318-324.
4. Сенюта І.Я. Цивільні правовідносини у сфері надання медичної допомоги в Україні: питання теоpiї і практики : дис. ... докт. юрид. наук : 12.00.03. Київ, 2018. 500 c. URL: https://drive.google.com/file/ d/19_d8Sllb7tQzbyfYTaWSA7p1EDiZIUy/view.

5. Герц А.А. Договірні зобов'язання у сфері надання медичних послуг : дис. ... докт. юрид. наук : 12.00.03. Львів, 2016. 421 c. URL: http://idpnan.org. ua/files/gerts-a.a.-dogovirni-zobov_yazannya-usferi-nadannya-medichnih-poslug-_d_.pdf.

6. Булеца С.Б. Цивільні правовідносини, що виникають у сфері здійснення медичної діяльності: теоретичні та практичні проблеми : дис. ... докт.-ра юрид. наук : 12.00.03. Одеса, 2016. 437 c. URL: http://dspace.onua.edu.ua/bitstream/ handle/11300/3307/Buletsa_S_B_disertatsiya. pdf? sequence $=14 \&$ is Allowed $=y$.

7. Приватне право в сфері охорони здоров'я: виклики та перспективи. Київські правові читання : мат. Міжнарод. наук.-практ. конф. (Київ, 17 вересня 2020 р.) / відп. ред. Р.А. Майданик. Львів : ЛОБФ «Медицина і право», 2020. 264 с.

8. Principles, Definitions and Model Rules of European Private Law. Draft Common Frame of Reference (DCFR). Outline Edition. Munich : Sellier, 2009. P. 60-99. URL: https://www.law. kuleuven.be/personal/mstorme/2009 02 DCFR OutlineEdition.pdf.

9. Миронова Г.А. Приватноправове регулювання особистих немайнових відносин у сфері надання медичної допомоги : дис. ... докт. юрид. наук : 12.00.03. Київ, 2020. С. 68, 96, 98, 139.

10. COVAX No-Fault Compensation Program for AMC Eligible Economies. URL: https:// covaxclaims.com/program-protocol/.

11. Bernhard A. Koch. Medical Malpractice in Austria. Medical Malpractice and Compensation in Global Perspective / Ken Oliphant, Richard W. Wright (eds). Berlin ; Boston : Walter de Gruyter, 2013. P. 31

12. Kinga Bączyk-Rozwadowska. Medical Malpractice and Compensation in Poland. Chicago-Kent Law Review. 2011. Vol. 86. Issue 3. P. 1220-1221.

13. Medical Liability and Patient Law in Germany: Main Features with Particular Focus on Treatments in the Field of Interventional Radiology / S.A. Sommer, R. Geissler, U. Stampfl, M.B. Wolf, B.A. Radeleff, G.M. Richter, H.-U. Kauczor, P.L. Pereira, C.M. Sommer. RöFo - Fortschritte auf dem Gebiet der Röntgenstrahlen und der bildgebenden Verfahren. Stuttgart ; New York : Georg Thieme Verlag KG, 2016. Vol. 188. Issue 4. P. 353-358.

14. Giovanni Comandé. Italy. In International Encyclopaedia of Laws: Medical Law edited by Herman. Alphen aan den Rijn : Kluwer Law International, 2014. P. 161.

Volodymyr Prymak. Compensation for damages due to vaccination from COVID-19

The article examines the legal problems caused by the intersection of the spheres of functioning of different legal mechanisms - respectively, mainly private or public law regulation of relations for compensation of damage caused to patients and others persons due to actions or omission of health care professionals, health care providers in the first place. The peculiarities of the interaction of tort law and conditional insurance's (social, based on the idea of solidarity) direction, introduced by the latest domestic "anti-COVID" legislation 
and international legal provisions of the COVAX Now-Fault Compensation Program for AMC eligible Economies are considered.

It is noted that in contrast to the COVAX No-Fault Compensation Program, the national legal mechanism established by the Cabinet of Ministers of Ukraine dated 31.03.2021 № 371 "Some issues of state compensation for damage related to complications that may occur after vaccination against acute respiratory disease COVID-19 caused by coronavirus SARS-CoV-2” does not cover such legally significant aspects of legal protection of victims as: representation of the interests of the victim; a wide range of significant manifestations of harm that can be caused by vaccination (the relevant list cannot be limited to such circumstances as the death of an individual or his disability); establishing a reliable standard of causation (such as the most probable cause standard under the COVAX No-Fault Compensation Program); administrative procedure for appealing the decision of the authorized body; the possibility of legal succession (including procedural) in relation to the requirements of the deceased patient; the procedure for exchanging confidential information about the patient; taking into account the legal consequences of unscrupulous actions of applicants (for compensation) and third parties, etc.

Key words: COVID-19 pandemic, emergencies, civil (contractual or tortious) liability, patient, health care providers, disability, vaccine. 